\title{
VÉKONYLEMEZ HENGERÍTÉSI FOLYAMATÁNAK NUMERIKUS MODELLEZÉSE
}

\section{NUMERICAL MODELLING OF THE THREE-ROLL BENDING PROCESS OF A THIN PLATE}

\author{
Máté Péter, ${ }^{1}$ Szekrényes András ${ }^{2}$ \\ Budapesti Müszaki és Gazdaságtudományi Egyetem, Budapest, Magyarország \\ 1 matepeter95@gmail.com \\ 2szeki@mm.bme.hu
}

\begin{abstract}
The three-roll bending process is a simple procedure, commonly used in the industry, through which a cylindrical surface can be produced from a sheet plate. This process is mainly controlled through experience and it is described with the finite element method, except for a very few numerical and analytical investigations. The topic of this article is to present a numerical method, through which the curvature function along the rolling direction can be calculated. This article presents the proposed numerical method and its verification with the finite element method. The results of the two numerical methods are in good agreement.
\end{abstract}

Keywords: sheet metal, three-roll bending, metal forming, residual curvature.

\section{Összefoglalás}

A lemezhengerítés egy, az iparban gyakran használt, viszonylag egyszerű eljárás, amely segítségével sík lemezből hengerpalást állítható elő. A folyamatot leginkább tapasztalati úton kezelik, leírására pedig,kevés kivétellel, legtöbbször véges elemes modellek születtek. A cikk témája egy olyan saját numerikus eljárás bemutatása, amely segítségével kiszámítható a lemezgörbület lefutása adott paraméterek mellett. A cikkben bemutatom a nemlineáris numerikus eljárást, illetve ennek a végeselem-módszerrel történő ellenőrzését. A végeselem-módszer eredményei megfelelő pontossággal követik az algoritmus által számolt értékeket.

Kulcsszavak: lemez, hengerítés, képlékeny alakítás, maradó görbület.

\section{Bevezető}

A hengerítési folyamat maga gyakorlatilag egy olyan hárompontos hajlítás, amelyen áttoljuk a lemezt, így annak minden pontja hajlítást szenved el. A berendezés két alsó és egy felső görgőből áll, úgy, hogy a felső görgő az alsó kettő között helyezkedik el. A lemezt behelyezzük a három görgő közé, majd a középső görgő függőleges elmozdításával terheljük a lemezt a 1 . ábra szerint. Az alsó görgők együttes forgatásával mozgásra kényszerítjük a lemezt, bár extrémebb esetben a felső görgő hajtása is indokolt lehet. A folyamatos eltolással a lemez minden pontját meggörbítjük, ezáltal hengerfelületet hozva létre.

\section{Lemez modellezése}

A modellezéshez választott rugalmas-képlékeny anyagmodell a rugalmas-lineárisan izotróp keményedő, más néven Von Mises-féle bilineáris modell. Ennek a húzógörbéje az 2. ábrán található. Ez a modell jól alkalmazható kis alakváltozások és viszonylag egyenes plasztikus karakterisztikájú anyagok esetén, illetve az erre való alapozással a számítási algoritmus könnyen kiegészíthető egy multilineáris anyagmodell adoptálására. 


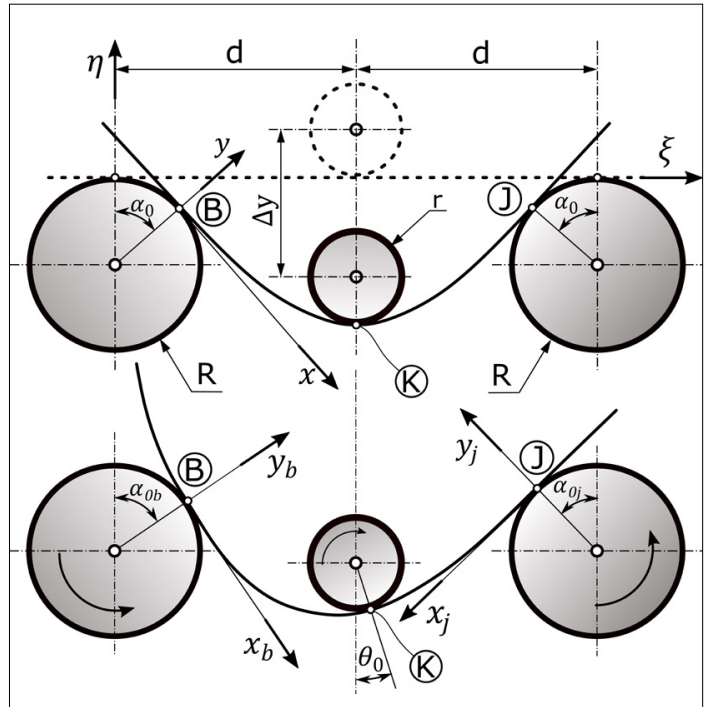

1. ábra. A szerkezet bemutatása: első terhelés (felül) és eltolás (alul)

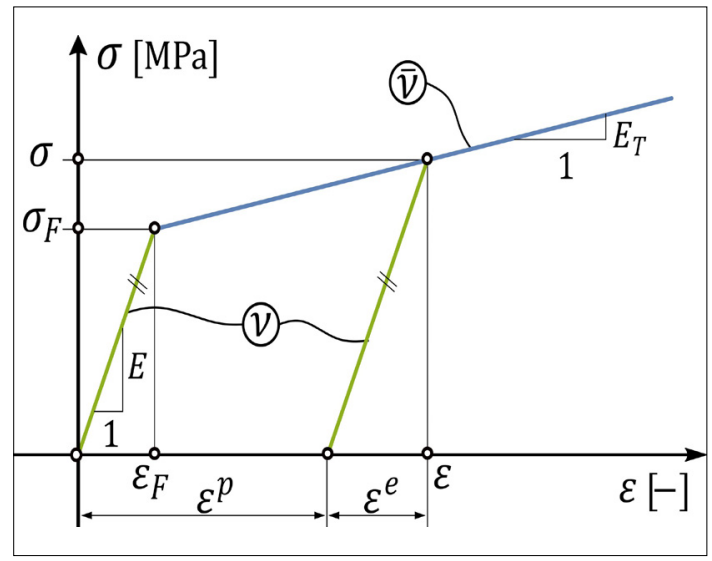

2. ábra. A bilineáris modell húzógörbéje

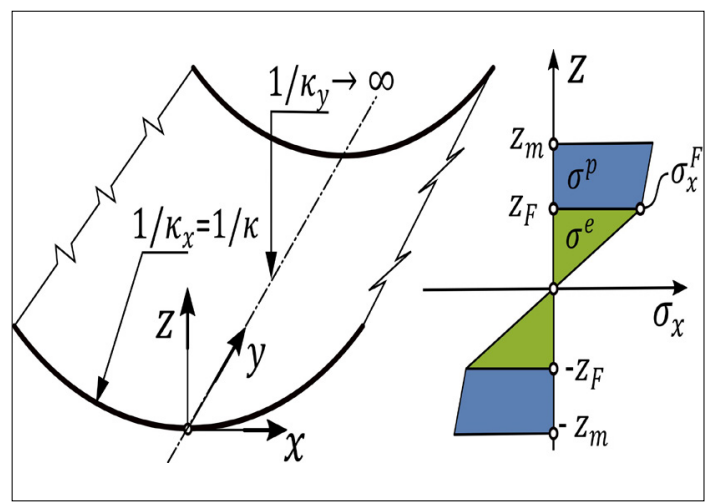

3. ábra. Lemezhajlítás és feszültségeloszlás
A rugalmas tartománybeli feszültség és alakváltozás összefüggését az (1) egyenletben található Hooke-törvény adja meg, amelyet a (2) egyenlet szerint adaptáltam a képlékeny tartományra, a kezdőpont $\left(\sigma_{F} ; \varepsilon_{F}\right)$ pontba való eltolásával. A továbbiakban a Kirchhoff-féle lemezmodellt használom. A konstitutív egyenletben szereplő feszültség- és alakváltozási paraméterek a lemez középsíkjához kötött lokális koordinátarendszerben vannak leírva. A lemezt kizárólag hajlítás terheli, ennek vázlata a 3 . ábrán látható.

A lemezben az $x$ irányú fajlagos nyúlás az $\varepsilon_{X}=\kappa \cdot z$ képlet szerint alakul.

$$
\begin{aligned}
\boldsymbol{\sigma}^{e} & =\left[\begin{array}{l}
\sigma_{x}^{e} \\
\sigma_{y}^{e}
\end{array}\right]=+\frac{E}{1-v^{2}} \cdot \kappa \cdot z\left[\frac{1}{v}\right] \\
\boldsymbol{\sigma}^{\mathbf{p}} & =\left[\begin{array}{c}
\sigma_{x}^{p} \\
\sigma_{y}^{p}
\end{array}\right]=\left[\begin{array}{l}
\sigma_{x}^{F} \\
\sigma_{y}^{F}
\end{array}\right]+\frac{E_{T}}{1-(\bar{v})^{2}} \cdot \kappa \cdot\left(z-z_{F}\right)\left[\frac{1}{\bar{v}}\right]
\end{aligned}
$$

A folyási határ paramétereihez Huber-MisesHencky-féle egyenértékű feszültséget használom fel. A rugalmas zóna határán fennálló feszültségállapot a (3) képlet szerint alakul.

$$
\boldsymbol{\sigma}^{\mathbf{F}}=\left[\begin{array}{c}
\sigma_{x}^{F} \\
\sigma_{x}^{F}
\end{array}\right]=\frac{\sigma^{F}}{\sqrt{1-v+v^{2}}} \cdot\left[\begin{array}{l}
1 \\
v
\end{array}\right]
$$

Fontos továbbá ismerni a lemezen belüli rugalmas és rugalmas-képlékeny zónák határát, illetve, hogy milyen terhelésnél jelentkezik folyás. Ehhez definiálom a határgörbületet és a lemezvastagság mentén a zónahatárt az (4) és (5) egyenletek szerint.

$$
\begin{aligned}
& \kappa_{H}=\frac{\sigma^{F}}{z_{m}} \cdot \frac{1}{E} \cdot \frac{1-v^{2}}{\sqrt{1-v+v^{2}}} \\
& z_{F}=\frac{\sigma^{F}}{\kappa} \cdot \frac{1}{E} \cdot \frac{1-v^{2}}{\sqrt{1-v+v^{2}}}
\end{aligned}
$$

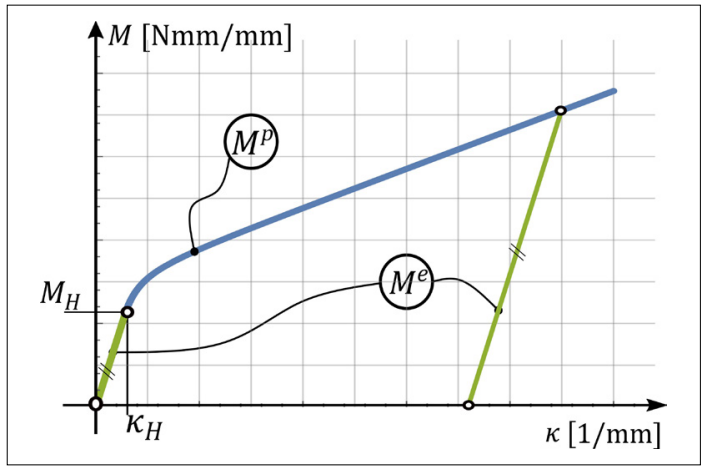

4. ábra. A lemez hajlítógörbéje 
A lemez hajlításához szükséges élnyomaték a feszültségmező integrálásából adódik. Az elasztikus $\left(M^{e}\right)$ és a már megfolyt $\left(M^{p}\right)$ állapotban szükséges nyomatékok összefüggései a (6) és (7) képletek szerint alakulnak , a görbülettől való függésük a 4. ábrán látható.

$$
\begin{aligned}
& M^{e}(\kappa)=\lambda \cdot \kappa \\
& M^{p}(\kappa)=a+\frac{b}{\kappa^{2}}+c \cdot \kappa
\end{aligned}
$$

Az $a, b, c, \lambda$ anyag- és geometriafüggő konstansok, a (8)-(11) egyenletek szerint.

$$
\begin{aligned}
& \lambda=\frac{2}{3} \cdot \frac{E}{1-v^{2}} \cdot z_{m}{ }^{3} \\
& a=\frac{z_{m}{ }^{2} \cdot \sigma^{F}}{\sqrt{1-v+v^{2}}} \cdot\left(1-\frac{E_{T} \cdot\left(1-v^{2}\right)}{E \cdot\left(1-\bar{v}^{2}\right)}\right) \\
& b=\frac{\sigma_{F}{ }^{3} \cdot\left(v^{2}-1\right)^{2} \cdot\left(E+E_{T} \cdot\left(v^{2}-1\right)-\bar{v}^{2} \cdot E\right)}{3 \cdot E^{2} \cdot\left(1-v+v^{2}\right)^{\frac{3}{2}} \cdot\left(\bar{v}^{2}-1\right)} \\
& c=\frac{2 \cdot E_{T} \cdot z_{m}{ }^{3}}{3 \cdot\left(1-\bar{v}^{2}\right)}
\end{aligned}
$$

\subsection{A plasztikus Poisson-tényező}

A plasztikus tartományban elfogadott a feltételezés, hogy az alakváltozás képlékeny komponense nem okoz dilatációt [1]. Ha ezt alkalmazom a bilineáris anyagmodellre, a (12) egyenlet adódik. Az összefüggés levezetése az egytengelyű húzásra történt, de feltételezem, hogy a kapott Poisson-tényező $\left(v_{p}\right)$ bármilyen alakváltozási állapotra érvényes.

$v_{p}\left(\varepsilon_{x}\right)=\frac{1}{2}-\left(\frac{1}{2}-v\right) \cdot\left[\frac{\varepsilon_{F}}{\varepsilon_{x}}+\frac{E_{T}}{E} \cdot\left(1-\frac{\varepsilon_{F}}{\varepsilon_{x}}\right)\right]$

Arra való tekintettel, hogy a konstitutív egyenletben szereplő Poisson-tényező csak a folyáshatár utáni tartományra vonatkozik, definiálom a $\bar{v}$-t a (13) egyenlet segítségével.

$$
\bar{v}=\frac{\varepsilon_{y}-\varepsilon_{y}^{F}}{\varepsilon_{x}-\varepsilon_{x}^{F}}=\frac{1}{2}-\left(\frac{1}{2}-v\right) \cdot \frac{E_{T}}{E}
$$

\section{Numerikus modell}

\subsection{Modellezési eszközök}

Mivel a lemeznek csak az egyik irányban létezik zérustól különböző görbülete, ezért az jellemezhető a középsíkjának a hengerek tengelye menti vetületével az 5 . ábra szerint. A lemezt hosszában véges számú, $\Delta s$-hosszúságú elemből építem fel, ahol az egyes csomópontokhoz tartozó paraméterek numerikus integrálás eredményei. A lemezt továbbá jobb és bal oldali részre osztom, majd addig iterálom a lemezre ható erőket amíg a két lemezrész megfelelő közelítéssel egy másodrendben folytonos görbét alkot, úgy, hogy közben ugyanazon, $\boldsymbol{K}$ pontban érintői a középső görgőnek. Az érintkezési csomópont indexe mindig „ $i_{0}$. Az első terhelésnél elegendő az egyik oldali lemezrész számítása a szimmetria miatt. Eltolás esetén megbomlik a szimmetria, így külön vizsgálni kell a két alsó görgőn ébredő erőt. Az egyes csomópontokra a rekurziót a (14)-(18) képletekkel adom meg.

A folyamatot az alsó görgőkön ébredő erő vezérli, így indirekt módon adódik az összefüggés a középső henger elmozdulása és a görbületfüggvény között. Az eltolást a lemez újbóli, adott számú csomóponttal áthelyezett terhelésével modellezem [2]. A terhelés és az érintkezési pont eltolódása csak a $\boldsymbol{B}$ pontra van kikötve, a többi kiadódik a számításból.

$$
\begin{aligned}
& M_{i}=\left(x_{i-1}+\Delta s \cdot \cos \left(\varphi_{i-1}\right)\right) \cdot|\mathbf{f}| \\
& \kappa=\left\{\kappa^{*} \mid M_{i}=M\left(\kappa^{*}\right)\right\} \\
& \varphi_{i}=\varphi_{i-1}+\Delta s \cdot \frac{\kappa_{i}+\kappa_{i-1}}{2} \\
& x_{i}=x_{i-1}+\Delta s \cdot \cos \left(\frac{\varphi_{i}+\varphi_{i-1}}{2}\right) \\
& y_{i}=y_{i-1}+\Delta s \cdot \sin \left(\frac{\varphi_{i}+\varphi_{i-1}}{2}\right)
\end{aligned}
$$

A (15) egyenletben a görbület a megfelelő (6) vagy (7) képletből számítandó. A szögelfordulás megfelelő numerikus integrálásához legalább másodfokú parabolát kell illeszteni szakaszonként a görbületfüggvényre, majd végül a parabolát integrálni.

\subsection{Kontaktpont keresése}

Első terhelésnél a szimmetria kihasználása miatt az 5. ábrán látható $\theta_{0}$ eltűnik, és a kontaktpontban $\alpha_{0}^{\prime}=\varphi_{i_{0}}$. Így elég azt a csomópontot keresni, ahol a (19) egyenlet teljesül.

$$
d=\left(R+y_{i_{0}}\right) \cdot \sin \left(\varphi_{i_{0}}\right)+x_{i_{0}} \cdot \cos \left(\varphi_{i_{0}}\right)
$$

Eltolás esetén a megbomlott szimmetria miatt a középső görgőn elmozdul a $\boldsymbol{K}$ pont $\theta_{0}$ szöggel. $\mathrm{Az}$ 5. ábrán látható $\boldsymbol{\rho}$ vektor már konstansnak számít, és a $\xi-\eta$ rendszerben adott. A feladat itt 
az $\alpha_{0}{ }^{\prime}$ szög keresése. A megoldáshoz a (20) egyenlet szerint számoljuk az $\alpha_{0}^{\prime}$ szög szinuszát és koszinuszát. Megoldás ott van, ahol ezek megfelelő pontossággal kielégítik a Pitagorasz-tételt.

$$
\left(\begin{array}{c}
\cos \left(\alpha_{0}^{\prime}\right) \\
\sin \left(\alpha_{0}^{\prime}\right)
\end{array}\right)=\left(\begin{array}{cc}
\rho_{\xi} & -\rho_{\eta} \\
\rho_{\eta} & \rho_{\xi}
\end{array}\right)^{-1} \cdot\left(\left(\begin{array}{l}
x_{i_{0}} \\
y_{i_{0}}
\end{array}\right)-\mathbf{r}_{1}-\mathbf{r}_{2}\right)
$$

\section{Következtetések}

Azonos anyagi és gépi paraméterek mellett, négy csomópontos síkelemekkel végzett szimuláció eredményei összehasonlítva a numerikus eljárással a 6. ábrán láthatóak. A véges elemhez használt elemek síkfeszültségi állapotban vannak. A vastagság mentén a felbontáshoz 8 elemet alkalmaztam, A. Ktari et al. [3] alapján. Itt a görbületet három szomszédos, a középfelületen található csomópont köré írható kör sugara adja.

A 6. ábrán egy hozzávetőlegesen 35 mm-es eltolás után észlelhető görbületeloszlás van ábrázolva, a lemez gépből való eltávolítása nélkül, az ívhossz függvényében. A függvényen jelölt $\boldsymbol{B}, \boldsymbol{K}, \boldsymbol{J}$ pontok a 1. ábra szerinti érintkezési pontok helyei a folyamat leállítása pillanatában, míg a $\boldsymbol{K}^{0}$ jelű pont a legelső terhelésnél a középső görgővel való érintkezési pontot jelöli. Látható, hogy ott a legnagyobb a görbület, utána pedig egy exponenciálisan csökkenő harmonikus függvényhez hasonló alakot vesz fel.

A számításokhoz használt adatok az 1. és 2. táblázatban találhatóak.

A 6. ábrán szereplő függvények közötti relatív eltérés maximuma 3,2\%, így az eljárás megbízhatónak minősül további kutatáshoz.

\section{1. táblázat. Tesztadatok}

\begin{tabular}{|c|c|c|c|c|}
\hline $\begin{array}{c}\mathbf{E} \\
\text { [GPa] }\end{array}$ & $\begin{array}{c}\mathbf{E}_{\mathbf{T}} \\
\text { [GPa] }\end{array}$ & $\boldsymbol{v}$ & $\begin{array}{c}\mathbf{\sigma}_{\mathbf{F}} \\
\text { [MPa] }\end{array}$ & $\begin{array}{c}\mathbf{z m} \\
\text { [mm] }\end{array}$ \\
\hline 210 & 21 & 0.3 & 230 & 0.08 \\
\hline
\end{tabular}

2. táblázat. Tesztadatok

\begin{tabular}{|c|c|c|c|c|}
\hline $\begin{array}{c}\mathbf{R} \\
{[\mathbf{m m}]}\end{array}$ & $\begin{array}{c}\mathbf{r} \\
{[\mathbf{m m}]}\end{array}$ & $\begin{array}{c}\Delta \mathbf{y} \\
{[\mathbf{m m}]}\end{array}$ & $\begin{array}{c}\mathbf{d} \\
{[\mathbf{m m}]}\end{array}$ & $\begin{array}{c}\mathbf{\Delta s} \\
{[\mathbf{m m}]}\end{array}$ \\
\hline 7.5 & 4 & 4 & 13.5 & 0.001 \\
\hline
\end{tabular}

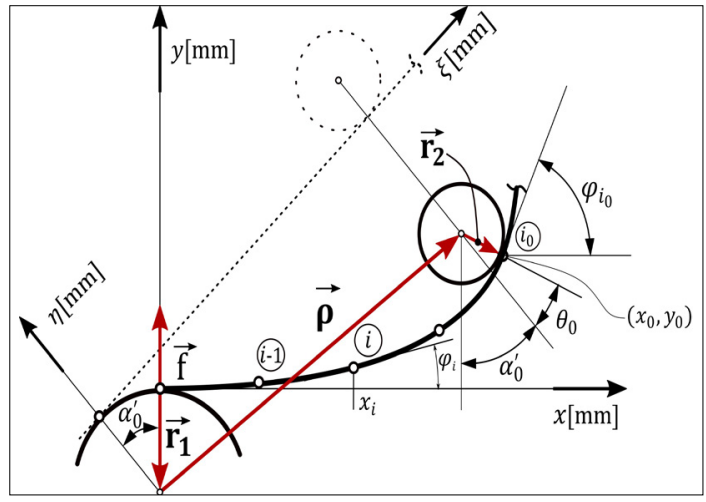

5. ábra. A lemez mechanikai ábrája

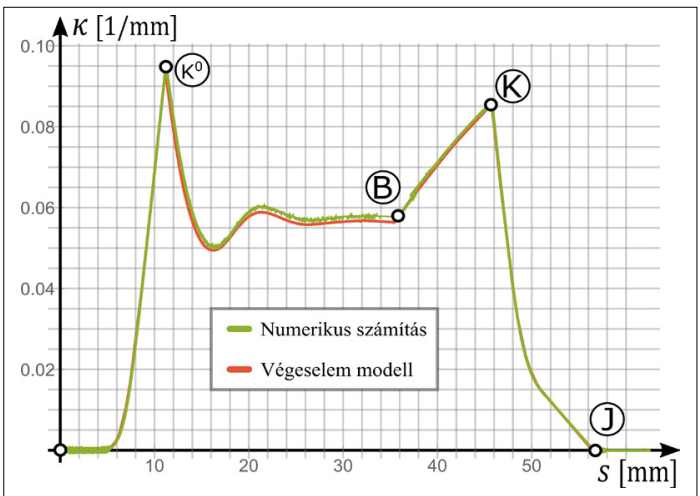

6. ábra. A numerikus eljárás összehasonlítása végeselem-módszerrel

\section{Szakirodalmi hivatkozások}

[1] Shin J. G., Lee J. H., Kim Y. I., Yim H.: Mechanicsbased determination of the center roller displacement in three-roll bending for smoothly curved rectangular plates. KSME International Journal, 15/12 (2001) 1655-1663. https://doi.org/10.1007/BF03185120

[2] NASA Technical Reports Server, A Study of Poisson's Ratio in the Yield Region. 1952. (letöltve: 2020. február 26.).

https://ntrs.nasa.gov/archive/nasa/casi.ntrs.nasa. gov/19930083272.pdf

[3] Ktari A., Antar Z., Haddar N., Elleuch K.: Modeling and computation of the three-roller bending process of steel sheets. Journal of Mechanical Science and Technology, 26 (2012) 123-128.

https://doi.org/10.1007/s12206-011-0936-4 